leucocyte ascorbic acid concentrations. ${ }^{4}$ Unfortunately the effects of treatment with vitamin $\mathrm{C}$ on drug metabolism were not recorded, but in animals drug handling is restored to normal after vitamin $C$ replacement. Certainly it seems wise to give patients with chronic liver disease multivitamin supplements which contain ascorbic acid.

${ }^{1}$ Leevy, C M, Thompson, A, and Baker, H, American fournal of Clinical Nutrition, 1970, 23, 493.

2 Morgan, A G, et al, Gut, 1976, 17, 113.

${ }^{3}$ Halsted C H, Robles, E A, and Mezey, E, Gastroenterology, 1973, 64, 526.

${ }^{4}$ Beattie, A D, and Sherlock, S, Gut, 1976, 17, 571.

5 O'Keane, M, Russell, R I, and Goldberg, A, fournal of Alcoholism, 1972 , 7, 6 .

6 Pelletier, O, Annals of the New York Academy of Sciences, 1975, 258, 156.

7 Goldberg, A, Quarterly fournal of Medicine, 1963, 32, 51.

${ }^{8}$ Ginter, E, Annals of the New York Academy of Sciences, 1975, 258, 410.

9 Zannoni, V G, and Sato, P H, Annals of the New York Academy of Sciences, $1975,258,119$.

\section{Consultant responsibility}

When Dr John Conolly was superintendent of Hanwell (now St Bernard's) Hospital, Middlesex, it enjoyed a reputation of excellence second to none in Britain. But the Board of Visitors (a lay body) meddled in the finances and policy-making of the hospital to a point where Conolly could suffer it no longer, and he resigned. Hanwell rapidly declined: three years after his departure it came to be described in the Middlesex County Lunatic Asylum Reports for 1855 and 1856 as "... an indifferently managed asylum-where lunatics are herded by the thousand, fed and clothed as paupers, but not treated as patients."

Conolly was an autocrat, albeit a benevolent one. In his day (though he would resent the expression if not the sentiment) the buck stopped at his desk. He made the decisions. There may well be an analogy between the decline in the fortunes of Hanwell and the parlous state of our mental hospitals today-that is, if the spate of elaborate, extremely costly, and demoralising inquiries is an index of their plight. No fewer than 14 such committees of inquiry have been held in the past ten years, a period which has seen the virtual elimination of medical authority. In its place there has arisen a diffuse, quasidemocratic, predominantly lay administration working through a multiplicity of committees. Committees may be able to formulate policies, but they cannot execute them. The result has been that there are now far more managers than ever before but far less management.

The Report of the Committee of Inquiry into St Augustine's Hospital, Canterbury, ${ }^{1}$ the latest of this seemingly endless line, has served, if nothing else to illustrate the current state of affairs. The diminished status of doctors is highlighted by two quotations: "Some [nurses] who have worked for many years in the hospitals without adequate assistance to keep up to date still regarded themselves as under the control of the doctors"; and, even more humiliating, "There must be an end to this wrong thinking. The consultant does not own the bed and has no more authority over it than the nurse." Yet, as a comment on the disintegration of management, the report stated: "We have already mentioned that the staff working in the hospital did not seem to know who was responsible for taking decisions if there were disagreements."

The changes in management were, no doubt, intended to introduce more democracy into hospitals. That intention has misfired, and something approaching anarchy has supervened. More and more strikes are called by one or other union representing groups of hospital workers-action which must in its very nature promote division in the hospital and adversely affect the morale of the staff and the quality of patient care. But, as a supreme example of the power of a union-power without responsibility, it could be added-is the scandal of Normansfield Hospital, where a consultant psychiatrist whose professional competence is not and has never been called into question was suspended from duty by' his employing authority merely because of threats by a trade union to deny all services to the hospital.

Again, nurses in mental hospitals are demanding more and more say in who is admitted and who is not. The protest at the moment concerns those admitted from the law courts, the socalled criminal cases. Hospital workers may well have a good case in respect of offenders under restriction orders (Section $60 / 65$ of the Mental Health Act 1959), in whom dangerousness can be presumed. But until (if ever) the local secure units come into being the alternative to admission to a mental hospital is a prison sentence, sometimes a life sentence. And now, according to a press statement: "Nurses belonging to the Confederation of Health Service Employees at Friern Hospital, north London, are to ban the admission of potentially violent patients." If the nurses really intend to ban all "potentially violent" patients then they must of necessity ban virtually all admissions, for who is not potentially violent? If, however, the inference is that all patients who have been brought before the courts should be banned, the nurses concerned have taken upon themselves the onerous responsibility of negating one of the fundamental and one of the most humane principles underlying the $1959 \mathrm{Act}$ : that if a person commits a crime and is found to be suffering from mental disorder he should receive treatment and not punishment.

In that context, would a criminal record of any sort at any time preclude admission ? Walker and $\mathrm{McCabe},{ }^{3}$ for example, showed in their survey of hospital orders (Section 60) made in the twelve months from April 1963 to March 1964 that some $50 \%$ of men and $36 \%$ of women had both previous convictions and previous hospital admissions. In this group of offenderpatients it is almost a matter of chance whether on any particular occasion an individual is admitted to hospital as an offender or as a patient, either informally or compulsorily. What, then, is the rationale of the nurses' action? Is it just muddled thinking, or is it yet another demonstration of unashamed, political, big-stick tactics?

How is the rot in management and in morale to be stopped in our mental hospitals ? How are they to be taken out of the cockpit of politics, so that the energies of all concerned may again be directed towards the treatment, the happiness, and the welfare of patients. There must, of course, be consultation among the various disciplines, as there was long before the talismanic slogan "multidisciplinary team work" was coined. Each of these disciplines is entitled to its own autonomy. But the ultimate control, the hand at the tiller, must be that of a designated member of the medical staff-call him chairman of the division of psychiatry, physician superintendent, or what you will. As it did with Dr Conolly, the buck must stop and be seen to stop at his desk.

1 South-east Thames Regional Health Authority. Report of Committee of Inquiry, St Augustine's Hospital, Chartham, Canterbury, 1976.

2 The Times, 29 January, 1977, p 3.

3 Walker, N, and McCabe, S, Crime and Insanity in England. Edinburgh, Edinburgh University Press, 1973. 